\title{
Protective effect of resveratrol on TNF- $\alpha$-treated vascular endothelial cells
}

\author{
Jingyu Xu, Yuan Lin, Ping Fu, Li Wang, Hua Li \\ From 2012 Sino-American Symposium on Clinical and Translational Medicine (SAS-CTM) \\ Shanghai, China. 27-29 June 2012
}

\section{Objectives}

Thrombomodulin (TM) is an important index of vascular endothelial injury. The present study was designed to investigate the effects and mechanims of resveratrol (RES) on TM in TNF- $\alpha$-injured vascular endothelial cell (VEC), and thus to provide a reliable experimental basis of RES for the endothelial function improvement and cardiovascular disease prevention.

\section{Methods}

1. VEC was treated with different concentration of TNF- $\alpha(0,1.25,2.5,5,10$ and $20 \mathrm{ng} / \mathrm{ml})$ for 4 hours. Then the content of NO and the activities of iNOS, and eNOS in the cell medium and lysates of VEC were determined, and the expression of TM was analyzed by using Western blot.

2. VEC was incubated with various concentrations of RES for 2 hours before adding $10 \mathrm{ng} / \mathrm{ml}$ TNF- $\alpha$. Then the content of NO, the activities of iNOS and eNOS were measured. The expression of TM was analyzed, and the activity of TM was determined by using thrombin time (TT) detection method.

3. VEC was incubated with various concentrations of SIRT1 inhibitor nicotinamide for $30 \mathrm{~min}$ before adding RES and TNF- $\alpha$.

\section{Results}

1. TNF- $\alpha$ increased the production and release of NO, the activities of iNOS, and TNF- $\alpha$ decreased the activity of eNOS significantly. It also reduced the expression of TM. Moreover, the optimal concentration of TNF- $\alpha$ for the injury of VEC was $10 \mathrm{ng} / \mathrm{ml}$.

2. Compared with TNF- $\alpha$-injured group, all RES treatments decreased significantly the content of NO,the

\footnotetext{
* Correspondence: dllihua@126.com

Department of Pharmacology, College of Pharmacy, Dalian Medical University, Dalian City, Liaoning Province, 116044, China
}

activity of iNOS, increased the activity of eNOS, and improved the expression and the activity of TM significantly.

3. Nicotinamide showed significantly inhibitory effects on the protective effects of RES.

\section{Conclusion}

1. VEC injury model was established successfully with TNF- $\alpha$ treatment.

2. RES showed significant protective effects on TNF$\alpha$-injured VEC, including the recovery of NO system, the increase of the expression and the activity of TM.

3. Nicotinamide inhibited the protective effects of RES, suggesting that this protective effect of RES be related to SIRT1 pathway.

Published: 17 October 2012

doi:10.1186/1479-5876-10-S2-A59

Cite this article as: Xu et al:: Protective effect of resveratrol on TNF- $\alpha$ treated vascular endothelial cells. Journal of Translational Medicine 2012 10(Suppl 2):A59.

Submit your next manuscript to BioMed Central and take full advantage of:

- Convenient online submission

- Thorough peer review

- No space constraints or color figure charges

- Immediate publication on acceptance

- Inclusion in PubMed, CAS, Scopus and Google Scholar

- Research which is freely available for redistribution

Submit your manuscript at www.biomedcentral.com/submit
C Biomed Central
C Biomed Central

(c) 2012 Xu et al; licensee BioMed Central Ltd. This is an Open Access article distributed under the terms of the Creative Commons Attribution License (http://creativecommons.org/licenses/by/2.0), which permits unrestricted use, distribution, and reproduction in any medium, provided the original work is properly cited. 